\title{
Determination of Academic Fraud by Using Communication Media as a Mediation Variable
}

\author{
Eka Wahyu Ramadiyani ${ }^{1}$, Sukirno ${ }^{2}$ \\ ${ }^{1}$ Postgraduate Student of Economic Education, Yogyakarta State University, Indonesia \\ ${ }^{2}$ Postgraduate Lecturer of Economic Education, Yogyakarta State University, Indonesia \\ Corresponding Author: Eka Wahyu Ramadiyani
}

\section{ABSTRACT}

The main purpose of education program is to develop the talent of students to become religious, noble character, democratic and responsible. Unfortunately, many students do not fully understand these objectives. They still consider academic achievement as the key to their future success. In order to get achievements, some even commit fraud. This is what underlies the background of this research to determine academic fraud in Vocational School students in Langkat Regency in terms of Fraud Pentagon Theory by including Mass Media as a mediating variable. The research method used is quantitative with the research subjects are Vocational School students in Langkat Regency, North Sumatra. Data collection was carried out through the distribution of Likert-type questionnaires. All research questionnaires were tested before being given to actual respondents and based on the results of validity and reliability testing, it was stated that all instruments were feasible to use. The data analysis used is Path Analysis using the SmartPLS Ver. 3 for Windows. The results showed: 1). Fraudulent Behavior has a positive and significant effect on Communication Media; 2). Communication Media has a positive and significant effect on Academic Fraud; 3). Fraudulent Behavior has a positive and significant effect on Academic Fraud; 4). Fraudulent behavior through Communication Media has a positive and significant effect on Academic Fraud at SMK Langkat Regency, North Sumatra. The suggestion in this research is that the role of parents and closest people is needed to make students aware that the main goal of education is not just achieving achievements, moreover get the achievements by fraud mechanism.

Keywords: Fraud Pentagon Theory, Academic Fraud, Vocational High School

\section{INTRODUCTION}

Education is one of the important pillars in creating a generation of people who morals and dignity. The national education system even become the important mandate in the Legislation of the Republic of Indonesia year 1945. The government then put serious attention in the education system in Indonesia, with an issued Law No. 20 year 2003 on National Education System (here in after called the ACT. 20/2003). As mentioned in Chapter 01 of the ACT. 20/2003, National Education is education based on Pancasila and the constitution of the Republic of Indonesia Year 1945, which is rooted in religious values, national culture of Indonesia and responsive to the demands of the changing times.

Ki Hajar Dewantara defines education as efforts to promote ethics, mind and physical well-being of the child, in order to advance the perfection of life that lives and turn the child that is in harmony with nature and the community (Hidayat and Abdillah, 2019). Whereas according to Article 01 of the ACT. 20/2003 described education is a conscious and planned effort to create an atmosphere of learning and learning process so that learners actively develop their potential to have spiritual 

variable.

strength of religious, self-control, personality, intelligence, noble character, and skills needed him, society, nation and state.

The system of national education according to Article 03 of the Law 20/2003 is to develop the potential of learners to become human beings who believe and fear year Forward, noble, healthy, knowledgeable, capable, creative, independent, and become a citizen that is democratic and responsible. Based on the definition and purpose of national education, then the function of national education is to develop the ability and form the character and civilization of a nation's dignity in the context of the intellectual life of the nation (Sugiyono, et al., 2013).

But unfortunately, the intent and purpose of education above, many of which are not well received in the community. People still tend to think of education only the pattern of the formation of cognitive learners' course. Khan and Khan (2011) stated that academic achievement as alatke alice, because it is considered that achievement will be easy to continue further education to school bona fide and even make it easier to get a job later. The community in this regard have already shifted their understanding, where the mandate of the act states the purpose of education is to form a personal attitude which is beneficial to the nation and the state, but infused the community as a medium for the development of the potential success of students, this eventually resulted in the purpose of education has become a tool of commercial (Joseph, 2018).

Furthermore, Joseph (2018) states, which happened in the world of education in the global era, is the occurrence of incomplete charge of education, or education that run in a limp. The perpetrators of education just catching the side of the materialist. As a result the progress obtained in the education of the only impact to the aspects that are materialsime anyway. Modern civilization was born to produce materialist humans, skilled in the fields of science, technology, master of information technology and business world, but dry of spiritual values which become the main mission of the education. So many smart people intellectually, but do not have the intelligence emotionally and spiritually. Education limp like this is what melahirlah the corruptor.

The ambition to be the best in school, sometimes even encourage learners get it by cheating. Conduct cheating or fraud is an act of fraud which is meant to bring about personal gain (Sorunke, 2016). According to Eastman (2008) stated that the cheating behavior specifically in the academic world can be in the form of cheating behavior at the time of working on an assignment, cheating on exam, and fraud by providing false information or fraud manipulate presence. This is in line with research Nursalam, et al (2013) who found that on the model of the cheating community is plagiarism work of a friend, do copy and paste, and open internet at the time of the exam. This is in line with research that is activated by Sagoro (2013) which revealed that the act of cheating on exam covering students bring a small note, students are asked to friends, and students who are trying to find leaked exam questions.

A number of theories try to explain why fraud occurs. Novita (2019) explain the three theories that surfaced is the Fraud Triangle Theory (FTT), Fraud Diamond Theory (FDT) and the Fraud Pentagon Theory. The third theory is trying to identify the elements driving the occurrence of fraud. FTT was first coined by Creessey in 1953 with the identify action fraud through three elements, namely: 1) perceived pressure, 2) opportunity, and 3) rationalization. Wolfe and Hermanson in 2004 and then adding a fourth element, namely the "capability", based on the consideration that the fraud may not be carried out successfully in the absence of the ability of an individual, and Horwarth in 2012 added a fifth element, namely the 

variable.

"arrogance" that is known by the Fraud Pentagon Theory.

Fraud Pentagon Theory describes the behavior of cheating students ' academic occur due to the 5 (five) factors, namely: the pressure (pressure), the opportunity (opportunity), rationalization (rationalization), competence (competence) or capability and personal ethics (personal ethics), or arrogance. Factors pressure (pressure) and the opportunity (opportunity) has the same meaning, namely because someone has the pressure so that there is a boost in order to make the cheating, someone has the opportunity to commit fraud because of the lack of supervision, and someone looking for a justification for the actions of such fraud.

Furthermore

competence

(competence) is similar to the ability or skill of understanding that is detailed so that someone can know your weakness and can use it to commit fraud. While personal ethics (personal ethics), namely the attitude of superiority over the rights to which are owned and felt that the internal audit or corporate policy does not apply to itself (Faradiza, 2018).

Cheating behavior in the academic world is very contrary to the purpose of education formed a personal noble. Cheating behavior struck in various educational institutions, where one of them occurred in the Vocational high School. A survey conducted by the Josephson Institute of Ethich found that about $70 \%$ of the 12,000 students of Vocational high School never cheating in the exam at least once within a period of a year. This Survey is then identified with the behavior outside the (academic) and found students tend to do the lie to both parents and to the teachers, even stealing (Ferguson, 2010). Approximately $35 \%$ of students of Vocational high School and Middle School students agreed with the statement: "I am willing to cheat when the exam if it can help me get into the University" (Rakovski and Levy, 2007). It is very unfortunate, especially vocational students, in particular accounting major in the future will work in the financial sector, both the recording and management. If the cheating behavior is constantly happening in the world of work, then it could have an impact not only on the environment, but can have a major impact for the culture of the company and the Country.

Research Zito, revealed that the cause of the behavior of academic fraud, among others: the moral decline of society, the culture of the educational institution where the cheating is considered normal, the belief that cheating is necessary to get a high score, and the availability of internet facilities to facilitate academic fraud. When students feel that the teachers don't understand about the internet then they will tend to do the plagiarism from the internet (Zito, 2009). The use of the internet as a medium of communication used it now should support ease of learning vocational students, but the abuse of the Communications Media to do cheating in the academic world also happens. Media Communication even easier for the learners to do the cheating.

The development of technology is basically intended to facilitate the work of man, including the practice of academic. However, Wood (Farida and Sari, 2015) found that the practice of cheating by using the internet as a Medium of Communication is still often occur. Triastuti, et al (2017) emphasize that the fraudulent activities by utilizing the internet as a Medium of Communication as one of the negative behavior of adolescents in accessing the internet. What they do, among others, utilizing the internet as a material of a cheat sheet, copy paste, no mention of the original source. It is not in line with what was stated by the Benawa (2010) where he stated that the Communications Media play an important role in the world of education, where the Communication Media can be a container the formation of the intellectual character of not only the learners but also to educators. 

variable.

The learning process is essentially communication, so the use of communication media is basically a medium for learning itself. There are 4 (four) of the Communications Media in learning, namely: 1) the Tool of the Physical, it is like a book, whiteboard, computer, has penetrated even into the medium of the internet; 2) Visual Aids, such as pictures, models, objects, props, shown to learners so that they can understand more easily against the material being taught; 3) Audio Aids, for example sound, a sound or any talk in the form of a file that can be opened at any time, and the last; 4) Direct Experience, it is related to what is directly experienced emotionally by learners, a touch more to the emotional touch (Benawa, 2010).

Based on the description above, it can be concluded that the purpose of education is to form personal as the next generation which is based on morals. But unfortunately, this goal is not many impregnated by learners and the surrounding environment, so as to make education as a gateway to the door of success. People believe, with academic achievement, it allows them to continue his career. In fact, in order to obtain good performance, there are some learners who commit fraud or fraudulent. It underlies people cheat among other: 1) pressure (pressure), the opportunity (opportunity), rationalization (rationalization), competence (competence) or the capability and personal ethics (personal ethics) or arrogance, where the overall factor is known with Fraud Pentagon Theory. In order to facilitate the learning process, then the Media Communication plays an important role in the support and facilitate education. Unfortunately, students who cheat actually utilizing the Media of Communication as tools that support people cheat them.

\section{LITERATURE REVIEW}

\section{Morality In The World Of Education}

Morality in the world of education is a major part in education system in Indonesia to become a man of faith and piety to God Almighty, noble, healthy, knowledgeable, capable, creative, independent, and become citizens of a democratic and responsible.

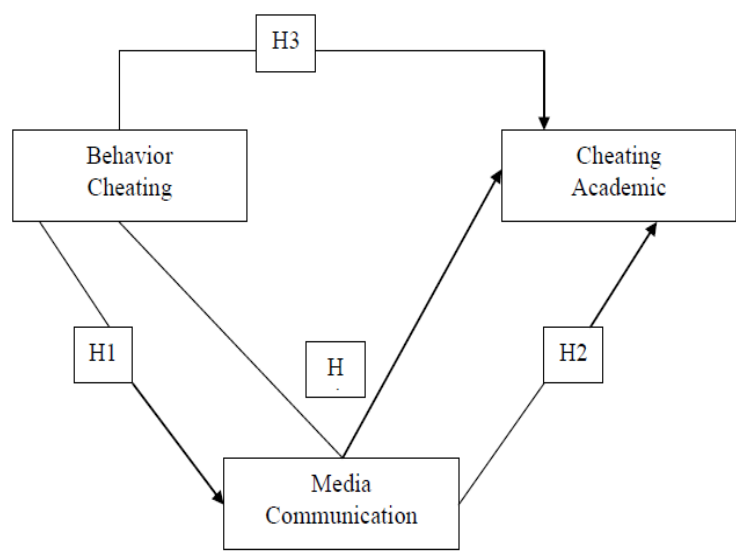

Figure 1. Conceptual Framework

\section{Behavior Cheat}

Fraud or cheating as action fraud and the criminal is meant to bring in an income, or personal gain to be able to fool others (Sorunke, 2016). According to Matthew, et al (2013) defines cheating in more detail, namely an act of fraud, a liquid intentional omission of the truth with the aim of. According to the Merriam Webster Dictionary of Law (1996) cheating is defined as part of an expression as an act, omission or concealment to be able to deceive other people.

\section{Academic Fraud}

Academic fraud as one of the behavior using ways that are not legitimate to achieve a result that is valid is to get an academic success or avoid a academic failure (Bowers, 1996).

\section{Media Communication}

Media communication is a tool or means used to convey the message from the communicator to the audience. The dominant Media in communicating is the five human senses such as ears and eyes. Media also is a window that allows us to be able to see the environment even further, as the interpreter that helps to understand the experience as a platform to disseminate information, as the interactive 

variable.

communication that includes the opinion of the audience, as a marker of the giver of instructions or instructions, as a filter or divider experience and focus on others, the mirror that reflects us and the barrier that covered the truth.

\section{Hypothesis}

Based on the background research and the relationship between variables, then the research hypothesis:

1. There is a positive and significant influence Cheating Behavior towards the Media of Communication in Vocational high School Langkat Regency, North Sumatra.

2. There is a positive and significant influence of Communication Media to the Academic Fraud in Vocational high School Langkat Regency, North Sumatra.

3. There is a positive and significant influence Cheating Behavior against Academic Fraud in Vocational high School Langkat Regency, North Sumatra.

4. There is a positive and significant influence Cheating Behavior against Academic Fraud through Communication Media in Vocational high School Langkat Regency, North Sumatra.

\section{MATERIAL AND METHODS}

This type of research is quantitative research to examine the factors that can influence the behavior of academic fraud on the students of Vocational high School. According to Sugiyono (2015) quantitative research methods can be interpreted as one of the research methods is based on the science of the philosophy of positivism, which is used to examine the population or a particular sample, the sampling technique is generally carried out at random, using a data collection instrument of the study, data analysis and quantitative / statistics with the aim to test the hypothesis that has been applied.

This research was conducted on the 11 (eleven) public and private schools in the District of Langkat. As for the studied school is SMKN 1 Stabat, SMKN $1 \mathrm{Tj}$. Pura, SMK negeri 1 Binjai, SMKS Harapan Stabat, SMKS Sri Langkat, SMKS Putra Jaya, SMKS Al ma'sum Stabat, SMKS Dharma Putra, SMKS Harapan Bangsa Kuala, SMKS Esa Initiative, and SMKS Al Jamiyatul wasliyah. The reason the researchers chose these schools is the level of academic fraud committed by students is low, as seen from the results of pre-survey that the researchers did in SMKN 1 Stabat as one of the state vocational high schools in the District. Langkat, which shows the level of cheating on the low student.

The population in this study were students of class XI in 11 (eleven) public and private vocational school in the District Stabat in the academic year 2020/2021 as many as 1000 students. The sampling technique used in this research is cluster sampling (area sampling). This technique is used "when where the population does not consist of individuals, but rather consist of groups of individual or cluster (Margono, 2004). Cluster sampling (area sampling) in this study is a sub-district in the District of Langkat. After cluster, followed by sampling proportionally every SMK. So the sampling techniques adopted are proportionate cluster sampling. Sampling does not distinguish between private schools and the country. So, the Number of samples that will be used in this research is the 290 respondents.

\section{RESULTS}

\section{Hypothesis Test}

\section{The Equation Of Line}

Structural equation obtained from the Chart of Path Analysis as in the following Image: 
Eka Wahyu Ramadiyani et.al. Determination of academic fraud by using communication media as a mediation variable.

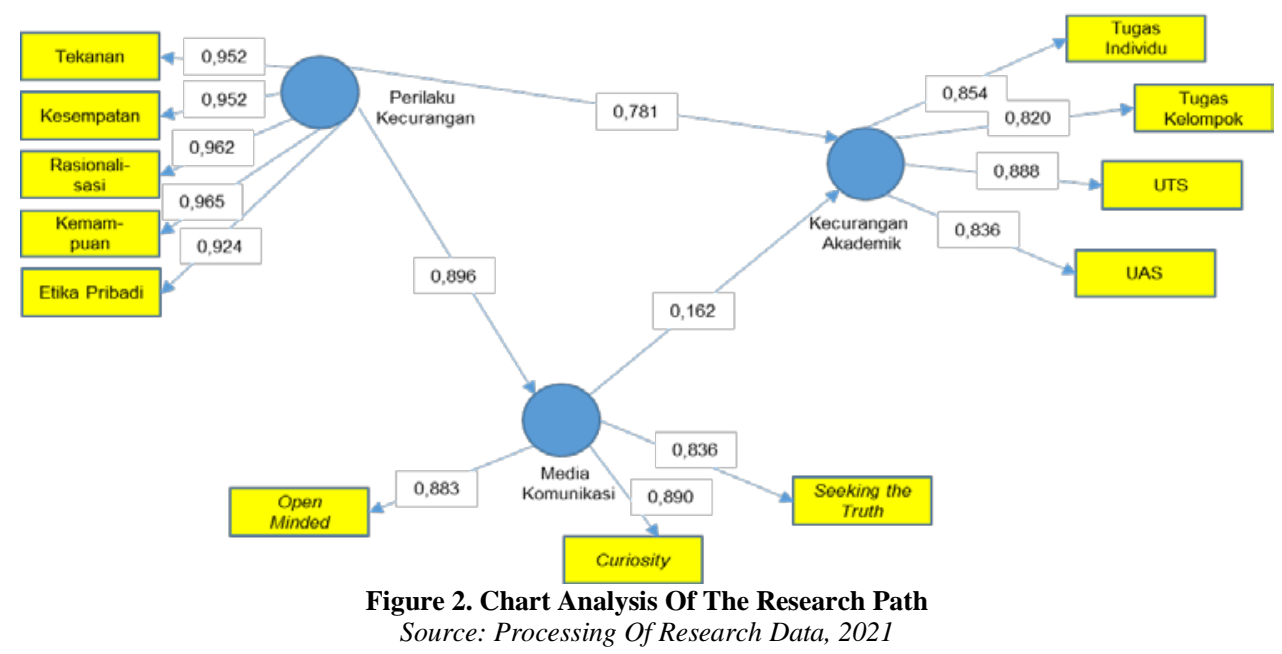

Based on the above, by looking at the chart of path analysis in figure 2, the obtained equations of structural I and II as follows:

Structural Equation I:

$Y 1=\beta X Y 1+e$

Where:

Y1 = Media Communication

$\beta=$ Constant

$\mathrm{e}=$ error

then the obtained:

$Y 1=0,896 X+0,198$

Structural equation II:

$Y 2=\beta X Y 2+\beta Y 1 Y 2+e$

Where:

Y1 = Media Communication

Y2 = Academic Fraud

$\beta=$ Constant

$\mathrm{e}=$ error

then obtained:

Next Pardede and Manurung (2014) revealed the interpretation of the correlation coefficient are outlined in Table 1 as follows:

Table 1. Interpretation Correlation Coefficient

\begin{tabular}{|l|l|}
\hline Value $\boldsymbol{r}$ & Criteria \\
\hline 0,00 s.d 0,29 & The correlation is very weak \\
\hline 0,30 s.d 0,49 & The correlation is weak \\
\hline 0,50 s.d 0,69 & Correlation \\
\hline 0,70 s.d 0,79 & Strong correlation \\
\hline 0,80 s.d 1,00 & The correlation is very strong \\
\hline
\end{tabular}

Referring to Table 1, then:

1. The magnitude of the direct influence Cheating Behavior against the Media
Communication of 0,802 where it shows a very strong correlation.

2. The magnitude of the direct influence Cheating Behavior against Academic Fraud by 0,781 where it indicates a strong correlation.

3. The magnitude of the direct influence of the Communications Media to the Academic Fraud of 0,162 where it indicates the correlation is very weak.

4. The magnitude of the indirect influence Cheating Behavior through Communication Media to the Academic Fraud obtained by multiplying the 0,896 with 0,162 obtained of 0.145 where it indicates the correlation is very weak.

By looking at the role of the direct influence of the Behavior of Academic Cheating to the Academic Fraud is large compared with the indirect influence of the Behavior of Academic Cheating to the Academic Fraud through Communication Media, it can be concluded that the role of Social Media as a mediating variable is not so significant to academic cheating.

\section{Outer Model}

Before seeing the results of the hypothesis test, it is necessary to ensure the measuring instrument has been tested for validity and reliability. In SmartPLS (v.3.2.8) testing the validity and reliability obtained through the outer model.

Validity is a measure that refers to the degree of fit between the data collected and the actual data in the data source 
Eka Wahyu Ramadiyani et.al. Determination of academic fraud by using communication media as a mediation variable.

(Sinulingga, 2018). An instrument is said to be valid if it is able to measure what he wants and can uncover data of the studied variables appropriately, while reliability indicates the extent to which the level of consistency of measurement from one respondent to another respondent, or in other words the extent to which the question can be understood so as not to cause different interpretations in understanding the question. In other words, reliability indicates the extent to which a relatively consistent measurement results if the measurement is repeated more than once.
Validity testing was conducted through the test of outer loading on the application of Pls (v 3.3.3) with criteria item questionnaire is valid if the correlation coefficient is above or equal to 0.7. The results of testing the validity found that of the 12 sub-dimensions to move in the range 0,820 until 0,965 , so that the overall item is worth at the time of taken this research because it has the validity of the above to 0.7. The results also showed not the discovery of trimming in the study, so the results of research deserve to be continued. The details can be seen in Table 2 following:

Table 2. Data Outer Loading on the Instrument of the Research

\begin{tabular}{|l|l|l|l|}
\hline & Cheating Academic & Media Communication & Cheating Behavior \\
\hline Personal Ethics & & & 0,924 \\
\hline The opportunity & & & 0,962 \\
\hline Competence & & & 0,965 \\
\hline Individual Tasks & 0,854 & & \\
\hline Task Group & 0,820 & & \\
\hline UTS & 0,888 & & \\
\hline UAS & 0,874 & & 0,962 \\
\hline Rationalization & & & 0,952 \\
\hline Pressure & & & \\
\hline Open Minded & & 0,883 & \\
\hline Curiosity & & 0,890 & \\
\hline Seeking the Truth & \multicolumn{2}{|l}{0,836} \\
\hline
\end{tabular}

While next obtained the results of the reliability test with Cronbach Alpha coefficient as in Table 3 below:

Table 3. The Results Of The Reliability Test Of The Questionnaire Research

Table 3. The Results Of The Reliability Test Of The Questionnaire Research
\begin{tabular}{|l|l|l|l|l|}
\hline & Cronbach's Alpha & rho_A & Composite Reliability & Average Variance Extracted (AVE) \\
\hline Academic Fraud & 0,882 & 0,885 & 0,919 & 0,739 \\
\hline Media Communication & 0,840 & 0,847 & 0,903 & 0,757 \\
\hline Cheating Behavior & 0,975 & 0,976 & 0,980 & 0,909 \\
\hline
\end{tabular}

Source: Processing Of Research Data, 2021

Based on the data on the Tabel7, the coefficient of Cronbach's Alpha move from 0,882 up 0,975 where all variables have a coefficient above 0.7 to so it can be concluded that the measuring instruments are reliable to be used.

\section{Inner Model}

Inner model aimed to see the results of research in accordance with the research hypothesis. There are 2 (two) types of proof the hypothesis in this study, namely the proof directly and verification indirect. As for proving the hypothesis directly indicated in accordance with Table 4 below:

Table 4. Direct Influence

\begin{tabular}{|l|l|l|l|l|l|}
\hline & $\begin{array}{l}\text { Original } \\
\text { Sample (O) }\end{array}$ & $\begin{array}{l}\text { Sample } \\
\text { Mean (M) }\end{array}$ & $\begin{array}{l}\text { Standard Deviation } \\
\text { (STDEV) }\end{array}$ & $\begin{array}{l}\text { T } \\
(\mid \mathbf{O} / \text { STDEV|) }\end{array}$ & $\begin{array}{l}\text { Statistics } \\
\text { Values }\end{array}$ \\
\hline Cheating Behavior -> Media Communication & 0,896 & 0,897 & 0,013 & 66,895 \\
\hline Communication Media ->Academic Fraud & 0,162 & 0,158 & 0,056 & 2,864 \\
\hline Cheating Behavior ->Academic Fraud & 0,781 & 0,786 & 0,054 & 14,563 \\
\hline
\end{tabular}



variable.

From Table 4 above, it is obtained that the Cheating Behavior has positive and significant impact of Communication Media in SMK Langkat Regency, North Sumatra, this is indicated by a significance value of $0.000<$ to 0.050 so that $\mathrm{H} 1-1$ accepted. Meanwhile, the Communication Media have a positive and significant impact on Academic Cheating SMK Langkat Regency, North Sumatra, this is indicated by the significance value of $0.004<$ to 0.050 so that H1-2 accepted. And, the Behavior of Cheating and significant positive effect on Academic Cheating SMK Langkat Regency, North Sumatra, this is indicated by a significance value of $0.000<$ to 0.050 so that the H1-3 is received.

As for proving the hypothesis indirectly through a variable between known through Table 5 here:

Table 5.The Influence Indirectly

\begin{tabular}{|l|l|l|l|l|l|}
\hline & $\begin{array}{l}\text { Original } \\
\text { Sample (O) }\end{array}$ & $\begin{array}{l}\text { Sample } \\
\text { Mean (M) }\end{array}$ & $\begin{array}{l}\text { Standard } \\
\text { Deviation } \\
\text { (STDEV) }\end{array}$ & $\begin{array}{l}\text { T Statistics } \\
(\mid \mathbf{O} / \text { STDEV|) }\end{array}$ & P Values \\
\hline $\begin{array}{l}\text { Cheating Behavior -> Communication } \\
\text { Media->Academic Cheating }\end{array}$ & 0,145 & 0,146 & 0,046 & 3,129 & 0,002 \\
\hline
\end{tabular}

Source: Research Data Processing, 2021

Based on the data in Table 5 above, it is obtained by indirectly proving the hypothesis that fraudulent behavior through communication media has a positive and significant effect on academic fraud at SMK Langkat Regency, North Sumatra, this is indicated by a significance value of $0.002<$ 0.050 so H1-4 is accepted.

\section{Determination Test}

Determination Test (R2) measures the extent to which the contribution of the independent latent variable to the dependent latent variable. The closer the value to 1.00 , the greater the contribution of the independent latent variable to the dependent latent variable, and vice versa (Sinulingga, 2017). The effects in detail are as follows:

1. R2 value of $>0.7$ is categorized as "strong"

2. R2 value of $0.67-0.7$ is categorized as "substantial"

3. $\mathrm{R} 2$ value of $0.33-0.66$ is categorized as "moderate"

4. R2 value of $<0.33$ is categorized as "weak"

While the value of $\mathrm{R} 2$ in this study are:

Table 6. Coefficient of Determination (R2)

\begin{tabular}{|l|l|l|}
\hline & R Square & Adjusted R Square \\
\hline Academic Cheating & 0,863 & 0,862 \\
\hline Communication Media & 0,802 & 0,801 \\
\hline \multicolumn{3}{|c|}{ Source: Research Data Processing, 2021} \\
\hline
\end{tabular}

\section{In Table 6 shows}

1. The value of the coefficient of determination for the latent variable of Academic Fraud is 0.863 or $86.3 \%$. This means that fraudulent behavior through communication media contributes $86.3 \%$ to the formation of academic fraud in SMK Langkat, North Sumatra, in this study, the remaining $13.7 \%$ is influenced by other factors not measured in this study.

2. The value of the coefficient of determination for the latent variable of Communication Media is 0.802 or $80.2 \%$. This means that the fraudulent behavior variable contributes $80.2 \%$ to the Communication Media at SMK Langkat Regency, North Sumatra, in this study, the remaining $19.8 \%$ is influenced by other factors not measured in this study.

\section{DISCUSSION}

This study shows that the Behavior of Cheating have direct effect on Academic Cheating. This study corroborates the results of previous studies, such as that done by Fitriana and Baridwan (2012); Fransiska and Utami (2019); Chen and Budiartha (2020). This research explains the reason the students of SMK di Kabupaten Langkat Sumatera Utara do the cheating behavior is influenced by 1) academic Pressure, 2) 

variable.

Opportunity, 3) Rationalization, 4) Competence, and 5) Personal Ethics or Arrogance.

The results of the research show, from 5 reasons fraudulent, as in Table 4 found that the reason for the "Pressure" is the main reason students cheating. This is indicated by the average score of the highest compared to any other reason. Students feel worried, if they don't get good grades, then they will be ostracized from other friends. This can be seen in one of the question items in the Questionnaire Cheating Behavior as the following:

Table 1. Questionnaire Items No. 03

\begin{tabular}{|l|l|l|l|l|}
\hline No & Statement & Average & Variant & Category \\
\hline 03 & $\begin{array}{l}\text { Friends play I'll stay } \\
\text { away from me if my } \\
\text { grades ugly. }\end{array}$ & 2,638 & 0,543 & "High" \\
\hline \multicolumn{4}{|c|}{ Source: Processing Of The Questionnaires, 2021 } \\
\hline
\end{tabular}

While the reasons for the low respondents' cheat is Personal Ethics, this is as indicated by the average value of the most low compared with other dimensions (as per data in the Table). This suggests that the shared values of a row fortify not to cheat.

According to Khan and Khan (2011) one reason or the motivation of the students doing the cheating behavior because they want to look outstanding, where achievement is still believed to be the key to success is good to get your favorite college or work later. This is in line with one of the question items in the questionnaire as follows:

Table 2. Questionnaire Items No. 28 and 43

\begin{tabular}{|l|l|l|l|l|}
\hline No & Statement & Average & Variant & Category \\
\hline 28 & $\begin{array}{l}\text { I do plagiarism in } \\
\text { the task group for } \\
\text { the good name I } \\
\text { can awake }\end{array}$ & 2,659 & 0,496 & "High" \\
\hline 43 & $\begin{array}{l}\text { I'm afraid of } \\
\text { losing the } \\
\text { achievements of } \\
\text { the class if I don't } \\
\text { do acts of } \\
\text { academic fraud. }\end{array}$ & 0,447 & "High" \\
\multicolumn{4}{|c|}{ Source: Processing Data Research } \\
\hline
\end{tabular}

In the Table 2 above shows that the motivation of students doing academic fraud is to maintain good name. They worry about their achievements slumped so embarrassed both self and family. Layard, et al (2013) in his study explained that the intellectual level only slightly affects the success of human in the future. Mental and physical health (as humans are still small) to be the main predictor of the future human. They stated that need attention for the people involved in the world of Education so as not to impose students for success in the academic world. Students are continuously motivated successful in the academic world; it eventually makes them stress and discomfort.

The results also show that the use of social media was influential to academic fraud. Indeed, the use of social media for learning is a positive thing and good. This is as mentioned in a study conducted by Rahman (2017), where he found that the use of social media can serve as a container looking for information related to school subjects, share the information to other colleagues or learn through a video tutorial. Action utilizes social media to conduct any cheat is the misuse of technology. Triastuti, et al (2017) stated need the support of family and people close to remind students to use and leverage social media a positive, not to cheat precisely make it easier to get information and tutorials related to their duties in the school.

Becker, et al. (2006) stated that students who are accustomed to doing academic fraud during school, then there is a tendency to do similar things when plunging into the world of work. This is in line with a paper presented by Spengler (2018) in the study of the length stated that the character of the students during the school will also affect their characters during his career. This suggests that if students have a good character in the lesson, then they will also be showing the same thing when they were working.

\section{CONCLUSIONS AND RECOMMENDATIONS CONCLUSIONS}

Based on the results of research and discussion that has been described in the 

variable.

previous chapter, it can be concluded as the following:

1. There is the influence Cheating Behavior with Communication Media in students of SMK in Langkat Regency, North Sumatra, it is indicated by the value of significance ( $\mathrm{p}$ values) of 0.000 $<0.05$.

2. There is the influence of Communication Media with Academic Fraud on the students of SMK in Langkat Regency, North Sumatra, it is indicated by the value of significance ( $p$ values) of $0,004<0,05$.

3. There is the influence Cheating Behavior with Academic Fraud on the students of SMK in Langkat Regency, North Sumatra, it is indicated by the value of significance ( $p$ values) of 0.000 $<0.05$.

4. There is the Influence Cheating Behavior through Communication Media to the Academic Fraud on the students of SMK in Langkat Regency, North Sumatra, it is indicated by the value of significance ( $p$ values) of 0.002 $<0,05$.

\section{Recommendations}

1. The results showed that the Cheating Behavior mediated the use of Communication Media proved influential on academic cheating. Schools and parents need to form a Committee of Supervision that can be comprised of Teachers and Representatives of parents of students, in order to monitor and cooperate so that the students apply the values of education in accordance with the objectives of National Education.

2. The research shows that the reason for the "Distressed" is the main reason the Students of SMK in Langkat Regency Sumatera Utara cheating. This needs to be a concern for educators, both Teachers and parents to give the understanding that they do not need to feel guilty with the surrounding environment if they are not outstanding.
Students need to be emphasized that the school not to compete to beat each other, instead forming a personal and skills.

3. The research also shows that the reasons of "Personal Ethics" be the reason most low. This suggests that the values that are embedded in students can help inhibit them cheat. Students also need to be given the understanding of the meaning of the purpose of education which is primarily precisely forming the morals and behavior of the charge.

4. It takes the role of parents and the people closest to aware the students that the main purpose of education is not just to achieve the feat, let alone achieve the feat with a way that is not true. Need special assistance for parents with reminds that the use of social media as a communication medium precisely to facilitate their learning.

5. In this study indicates that the Cheating Behavior contributed was $86.3 \%$, with other words, there is a $13.7 \%$ other factors that affect the Academic Fraud. This needs to be the attention for further research to examine other factors, such as the role of parenting or the exploration of identity.

\section{Acknowledgement: None}

\section{Conflict of Interest: None}

\section{Source of Funding: None}

\section{REFERENCES}

1. Abdullahi, R. dan N. Mansor. (2015). Fraud Triangle Theory and Fraud Diamond Theory: Understanding the Convergent and Divergent for Future Research. International Journal of Academic Research in Accounting, Finance and Management Sciences, Vol. 5, No. 4, Hal $38-45$.

2. Albrecht, W. S. (2012). Fraud Examination (Fourth Edition). USA: SouthWestern.

3. Anggola, V. (2020). Pengaruh Kecurangan Akademik Mahasiswa Dan Penyalahgunaan Teknologi Informasi Mahasiswa Terhadap Perilaku Integritas Mahasiswa Akuntansi Sebagai Calon Akuntan (Studi pada 
Eka Wahyu Ramadiyani et.al. Determination of academic fraud by using communication media as a mediation variable.

Mahasiswa Akuntansi Universitas Islam Indonesia). Skripsi. Yogyakarta: Universitas Islam Indonesia.

4. Aprilia, \& Aprilia, A. (2017). Analisis Pengaruh Fraud Pentagon terhadap Kecurangan Laporan Keuangan Menggunakan Beneish Model pada Perusahaan yang Menerapkan Asean Corporate Governance Scorecard. Jurnal ASET (Akuntansi Riset), Vol. 9, Hal. 101. https://doi.org/10.17509/jaset.v9i1.5259.

5. Becker, D., J.Connolly, P. Lentz dan J. Morrison. (2006). Using the Business Fraud Triangle to Predict Academic Dishonesty Among Business Students. Academy of Educational Leadership Journal.Vol. 10, No. 1, Hal. 37-54.

6. Benawa, A. (2010). Peran Media Komunikasi dalam Pembentukan Karakter Intelektual di Dunia Pendidikan. Jurnal IlmuKomunikasi, Vol. 2, No 1, Hal. 38 45.

7. Cizek, G.C. (2010). Cheating on Test: How to Do It, Detect It, and Prevent It. New Jersey: Lawrence Erlbaum Assocoates Inc. Publisher.

8. Cressey, D.R. (1950). The Criminal Violation of Financial Trust. American Sociological Review, Vol. 15, No. 6,Hal 115.

9. Crowe Horwarth. (2011). Why the Fraud Triangle is no Longer Enough. Article on Fraud. Crowe Horwath LLP.

10. Darwati. (2019). Pengaruh Fraud Pentagon terhadap Perilaku Kecurangan Akademik Mahasiswa Fakultas Ekonomi Universitas Negeri Semarang Angkatan 2015. Skripsi. Semarang: Universitas Negeri Semarang.

11. DeVito, J.(2001).The Nonverbal Communication Workbook (Prospect Heights). Illinois: Waveland Press.

12. Dharmesti, A. dan A. Djamhuri. (2019). Peran Teknologi Informasi Dalam Mengantisipasi Kecurangan Akuntansi (StudiKasus pada PT XYZ Tbk). Jurnal Ilmiah Mahasiswa FEB, Universitas Brawijaya. Vol. 8, No. 1, Hal. 1 - 10.

13. Duffield, G. dan P. Grabosky. (2001). Red Flag of Fraud. Trend and Issues in Crime and Criminal Justice, No. 200. Australian Institute of Criminology.

14. Eastman, J. K., R. Iyer, dan T.H. Reisenwitz. (2008). The Impact of Unethical Reasoning on Different Types of Academic Dishonesty: An Exploratory
Study. Journal of College Teaching \& Learning, Vol. V, No. 12, Hal. 7 - 16.

15. Fadilah, R., W.S. Alim, A.Zumrudiana, I.W. Lestari, A. Baidawi, dan A.D.Elisanti. (2021). Pendidikan Karakter. Bojonegoro: CV. Agrapana Media.

16. Faradiza, S.A. (2018). Fraud Pentagon dan Kecurangan Laporan Keuangan.Jurnal Ekonomi dan Bisnis, Vol. 2, No. 1, Hal. 1 22. ISSN 2549-4988.

17. Farida dan Sari. (2015). Media Tradisional VS Media Online, (Komunikasi dengan Keunikan Identitas). AT-TABSYIR: Jurnal Komunikasi Penyiaran Islam, Vol. 3, No. 1, Hal. 41 - 66 .

18. Febriana, N.R. (2019). Analisis Pengaruh Dimensi Fraud Pentagon Terhadap Perilaku Kecurangan Akademik Mahasiswa Pada Uji Kompetensi. Jurnal Ilmiah Mahasiswa FEB, Universitas Brawijaya. Vol. 8, No. 1, Hal. $11-33$.

19. Ferguson, L.M. (2010). Student SelfReported Acdemically Dishonest Behavior in Two-Year College in the State of Ohio. Disertasi. University of Toledo.।

20. Fitriana, A. dan Z. Baridwan. (2012). Perilaku Kecurangan Akademik Mahasiswa Akuntansi: Dimensi Fraud Triangle. Jurnal Akuntansi Multiparadigma (JAMAL). Vol. 3, No. 2, Hal. $242-254$.

21. Fransiska, I.S. dan H.Utami. (2019). Perilaku Kecurangan Akademik Mahasiswa: Perspektif Fraud Diamond Theory. Jurnal Akuntansi Aktual. Vol. 6, No. 2, Hal. 280 344. e-ISSN: 25801015; p-ISSN: 20879695.

22. Hair, J., R. Anderson, B. Black dan B. Babin. (2016). Multivariate Data Analysis. Pearson Higher Ed.

23. Hallak, J. dan M. Poisson. (2007). Corrupt Schools, Corrupt Universities: What Can Be Done? Paris: Institute for International Educational Planning. ISBN 10-92-8031296-0.

24. Hartanto, Dody. (2012). Bimbingan dan Konseling Menyontek: Mengungkap Akar Masalah dan Solusinya. Jakarta: PenerbitIndeks.

25. Hayes, D., K. Hurtt dan S. Bee.(2006). The War on Fraud: Reducing Cheating In The Classroom. Journal of College Teaching \& Learning, Vol. 3. No. 2, Hal. $1-12$.

26. Hendricks, B. (2004). Academic Dishonesty: A Study in the Magnitude of and Justification for Academic Dishonesty Among College Undergraduate and 
Eka Wahyu Ramadiyani et.al. Determination of academic fraud by using communication media as a mediation variable.

Graduate Students. Journal of College Students Development. Vol. 35, No. 12, Hal. $212-260$.

27. Hidayat, Rahmat, dan Abdillah. (2019). Ilmu Pendidikan, Konsep, Teori dan Aplikasinya. Medan: Lembaga Peduli Pengembangan Pendidikan Indonesia (LPPPI).

28. Irawan, M. (2017). Pengaruh Fraud Pentagon Terhadap Perilaku Kecurangan Akademik Mahasiswa Pendidikan Akuntansi Angkatan Tahun 2015 Universitas Negeri Semarang TahunAjaran 2016 / 2017. Skripsi. Semarang: Universitas Negeri Semarang.

29. Khan, Afnan, Alamgir Khan, Salahuddin Khan, Sami Ullah Khan dan Muhammad Khushdil Khan. (2011). Causes and Coping Strategies for Stress Among Employee. Journal of Physical Fitness, Medicine \& Treatment in Sports. Vol. 1, No. 4, Hal. 555 $-556$.

30. Kurnia, A.A., dan I. Anis. (2017). Analisis Fraud Pentagon dalam Mendeteksi Kecurangan Laporan Keuangan dengan Menggunakan Fraud Score Model. Journal of Simposium Nasional Akuntansi XX, 130.

31. Lambert, E.G, N.L. Hogan, S.M. Barton. (2003). Collegiate Academic Dishonesty Revisited: What Have They Done, How Often Have They Done It, Who Does It, and Why Didi They Do It? Electronical Journal of Sociology, Vo. 7, No.4.

32. Layard, Richard, A.E. Clark, F. Cornaglia, N.Powdthavee dan J.Vernoit. (2013). What Predicts a Successful Life?A Life-Course Model of Well-Being. IZA Discussion Paper No. 7682.

33. Margono.(2004). Metodologi Penelitian Pendidikan. Jakarta: Rineka Cipta.

34. Marks, J. (2010). Playing offense in a Highrisk Environment: Crowe Horwath LLP

35. Matthew, B.M. dan I.O. Kenneth. (2013). A Study on the Effects of Guided Inquiry Teaching Method on Students Achievement in Logic. International Researcher. Vol. 2, No. 1.

36. McCabe, D.L. dan L.K. Trevino. (1997). Individual and Contextual Influences on Academic Dishonesty: A Multicampus Investigation. Research in Higher Education, Vol. 38, No. 3, Hal. 379 - 396.

37. Merriam Webster Dictionary of Law. (1996).
38. Ningsi, E.H. (2018). Pengaruh Teknologi Informasi, Integritas, dan Kepercayaan Diri terhadap Perilaku Kecurangan Akademik (Studi Pada Mahasiswa Akuntansi STIE Eka Prasetya). Tesis. Medan: Universitas Muhammadiyah Sumatera Utara.

39. Novita, Nova. (2019). Teori Fraud Pentagon dan Deteksi Kecurangan Pelaporan Keuangan. Jurnal Akuntansi Kontemporer (JAKO). Vol. 11, No. 2, Hal. 64-73.

40. Nursalam, S.B., dan Munirah. (2013). Bentuk Kecurangan Akademik (Academic Cheating) Mahasiswa PGMI FakultasTarbiyah dan Keguruan UIN Alauddin Makassar. Jurnal Lentera Pendidikan, Vol. 16, No. 128, Hal. 127-138.

41. Rafita, Y. (2012). Analisis Faktor-Faktor Yang Mempengaruhi KecuranganAkademik (TitipAbsen) Pada Mahasiswa S1 Fakultas Matematika Dan Ilmu Pengetahuan Alam Universitas Islam Indonesia.Khazanah Jurnal Mahasiswa. Vol. 5, No. 2, Hal. 25 37.

42. Rakovski, Carter C.; Levy, Elliott S. (2007). Academic Dishonesty: Perceptions of Business Students. College Student Journal, Vol. 41, No. 2, Hal. 466 - 481.

43. Sagoro, E.M. (2013). Pensinergian Mahasiswa, Dosen, dan Lembaga dalam Pencegahan Kecurangan Akademik Mahasiswa Akuntansi. Jurnal Pendidikan Akuntansi Indonesia, Vol. XI, No.2, Hal. 54 $-67$.

44. Sekaran, Uma. (2006). Metode Penelitiaan Bisnis. Jakarta: SalembaEmpat.

45. Sihombing, Michael dan I.K Budiartha. (2020). Analisis Pengaruh Fraud Triangle Terhadap Kecurangan Akademik (Academic Fraud) Mahasiswa Akuntansi Universitas Udayana. E-Jurnal Akuntansi (EJA). Vol. 3, No. 20, Hal. 361 - 374. eISSN 2302-8556.

46. Situmorang, S.H. dan MuslichLufti. (2012). Analisis Data untuk Riset Manajemen dan Bisnis. Edisi 2. Medan: USU Press.

47. Sjarkawi (2008). Pembentukan Kepribadian Anak: Peran Moral Intelektual, Emosional, dan Sosial sebagai Wujud Integritas membangun Jati Diri. Cetakan Kedua. Jakarta: P.T.BumiAksara.

48. Sorunke, O. A. (2016). Internal Audit and Fraud Control in Public Institutions in Nigeria: Survey of Local Government Councils in Osun State. International Journal of Academic Research in Business 
Eka Wahyu Ramadiyani et.al. Determination of academic fraud by using communication media as a mediation variable.

and Social Sciences, Vol. 6, No. 2, Hal. 153-158.

49. Spengler. M., R.I. Damian dan B.W. Roberts. (2018). How You Behave in School Predicts Life Success Above and Beyond Family Background, Broad Traits, and Cognitive Ability. Journal of Personality and Social Psychology, 2018, Vol. 114, No. 4, Hal. 620-636. DOI: dx.doi.org/10.1037/pspp0000185

50. Sugiyono, Aman, Dyah Kumalasari, Sutopo dan ApriNuryanto. (2013). Peta Jalan Pendidikan Indonesia. Yogyakarta: Team UNY.

51. Sugiyono. (2015). MetodePenelitian Pendidikan Pendekatan Kuantitatif, Kualitatif, dan R\&D. Bandung: Alfabeta.

52. Sukiyat, D. (2020).Strategi Implementasi Pendidikan Karakter. Surabaya: CV Jakad Media Publishing.

53. Team PenyusunKamus Bahasa Indonesia. (2008). KamusB esar Bahasa Indonesia. Jakarta: Pusat Bahasa.

54. Triastuti, E., D. Adrianto dan A. Nurul. (2017). Kajian Dampak Penggunaan Media Sosial Bagi Anak dan Remaja. Jakarta: Pusat Kajian Komunikasi, FISIP Universitas Indonesia.

55. Tuanakota, T.M. (2015). Akuntansi Forensik dan Audit Investigatif. Jakarta: Salemba Empat.
56. Undang-undang Republik Indonesia No. 20 Tahun 2003 tentang Sistem Pendidikan Nasional.

57. Whitley dan B.E. Keith-Spiegel. (2002). Academic dishonesty: An Educator's Guide. Lawrence Erlbaum Associates Publishers.

58. Widarjono, Agus. (2015). Statistika Terapan, Edisi Pertama. Yogyakarta: UPP STIM YKPN

59. Wolf, D. T. dan D.R. Hermanson. (2004). The Fraud Diamond: Considering the Four Elements of Fraud.CPA Journal. Vol. 74, No. 12, Hal. 38-42.

60. Yusuf, Munir. (2018). Pengantar Ilmu Pendidikan. Palopo: Lembaga Penerbit Kampus IAIN Palopo.

61. Zanaria, Y. (2017). Pengaruh Aplikasi teknologi, Accounting Report terhadap Pencegahan Fraud serta Implikasinya terhadap Reaksi Investor. Jurnal AKUISISI, Vol. 3, No. 1, Hal. 91 - 100.

62. Zito, N.A. (2009). Engaging Middle School Students in School Work and its Effect of Cheating. Disertasi. Boston: Boston College University.

How to cite this article: Ramadiyani EW, Sukirno. Determination of academic fraud by using communication media as a mediation variable. International Journal of Research and Review. 2021; 8(11): 259-271. DOI: https://doi. org/10.52403/ijrr.20211134 